\title{
THE ANALYSIS OF MARKET CONCENTRATION IN HUNGARIAN TERTIARY EDUCATION THROUGH ENROLMENT DATA
}

\author{
Éva Réka Keresztes \\ $\mathrm{PhD}$ student in Management and Business Administration \\ Szent István University, Gödöllö, Hungary \\ E-mail: evakeresztes@gmail.com
}

\begin{abstract}
As a result of its dynamic growth, the service sector has become the dominant sector of national economies in developed countries. At the end of the $20^{\text {th }}$ century people began to perceive tertiary education as a service and this has brought about a change in their attitude towards higher education considering it as a commodity that can be bought. Non-business services like higher education are increasingly shaped by market forces and marketisation trends. The study examines the market structure of Hungarian higher education sector through enrolment data in Academic Year 2010-11. The paper presents various metrics of concentration based upon the number of students. The data analysis is performed using the Lorenz curve, the Gini index $(\mathrm{G})$, the concentration coefficient (C) and the Herfindahl-Hirschman index (HHI). The paper examines the market segmentation of higher education, specially focusing on the enrolment data of management and business studies of higher education.
\end{abstract}

Keywords: Tertiary education, Enrolment data, Marketisation trends, Market structure, Metrics of concentration

JEL classification: A22

\section{Introduction}

In developed countries, service sector has become the dominant sector of national economies as a result of its dynamic growth. The increased importance of the tertiary sector could be explained by its augmenting share in employment and production as a percentage of Gross Domestic Product. Service-oriented innovations are considered the drive of social and economic development in the 21 st century. Services play a complex role in economy and society, however, their common defining characteristics are that of human-centred and knowledge-intensive features. (Papp, 2003)

It is worth mentioning that higher education has played an important role in facilitating the process of globalisation, particularly in the integration of developing and emerging economies to the global production networks. (Golden and Schneller, 2010) Higher educational services can be categorised in several ways. Higher education falls into the category of serviceoccupations, which includes "non-productive" activities like hospitality or health care. (Gershuny and Miles, 1983) According to the characteristics of consumption, higher education belongs to the group of consumer services, which are sold directly to the consumer's personal use. (Papp, 2003) Higher education is a business-to-consumer (B2C) service type that is the seller is a business organization providing service to an individual consumer. (Turban, 2000) Higher education is considered a social service because the community (the state) ensures the framework requisited to meet individual and community needs. (Browning and Singelmann, 1998) 
The macro-level classification distinguishes market and non-market services according to their function in the national economy and their relation with market mechanisms. Higher education is considered a non-market service where the long-term interests of society cannot be in all respect fulfilled by the market. The majority of higher education services is organized by the state, as emerging resource allocation is inefficient through market mechanisms. Undoubtedly, economic and efficiency aspects should be taken into consideration in case of non-market services as well. According to the micro-level classification of services, higher education services are basically provided by non-profit organisations. (Papp, 2003) Higher education is a nonbusiness, not purely profit-oriented (noncommercial) class of services marketing. Statefunded higher education within the scope of nonbusiness services is considered to operate for public benefit, belonging to the public budgetary service sector. (Veres, 2004, 2009) Higher education belongs to quasi-public goods, as the possibility of rivalry and exclusion from consumption can be observed among consumers. (Farkasné and Molnár, 2007) Act CCIV of 2011 on national higher education sets the fundamental goal of raising the standards of higher education and providing the conditions necessary for the competitive knowledge transfer. Higher education institutions (HEIs) are organizations established for providing education, conducting scientific research and artistic creation as their basic activity. The Basic Law states that higher education institutions are self-sufficient regarding the contents and methods of research and teaching, and their organizational structure and management is regulated by law. The state is responsible for operating the system of higher education, while the upholder is responsible for the higher education institution. On behalf of the state the rights of the upholder - if the law does not provide otherwise - are exercised by the Minister of Education. (Jogtár, 2013)

\section{Methodology}

This study analyses the latest data on the number of students published by the Office of Education. In Academic Year 2010-11 there existed 69 higher education institutions (HEIs) in Hungary, among which 29 upheld by the state, 26 by the Church and 14 by foundations and private organisations. (Figure 1)

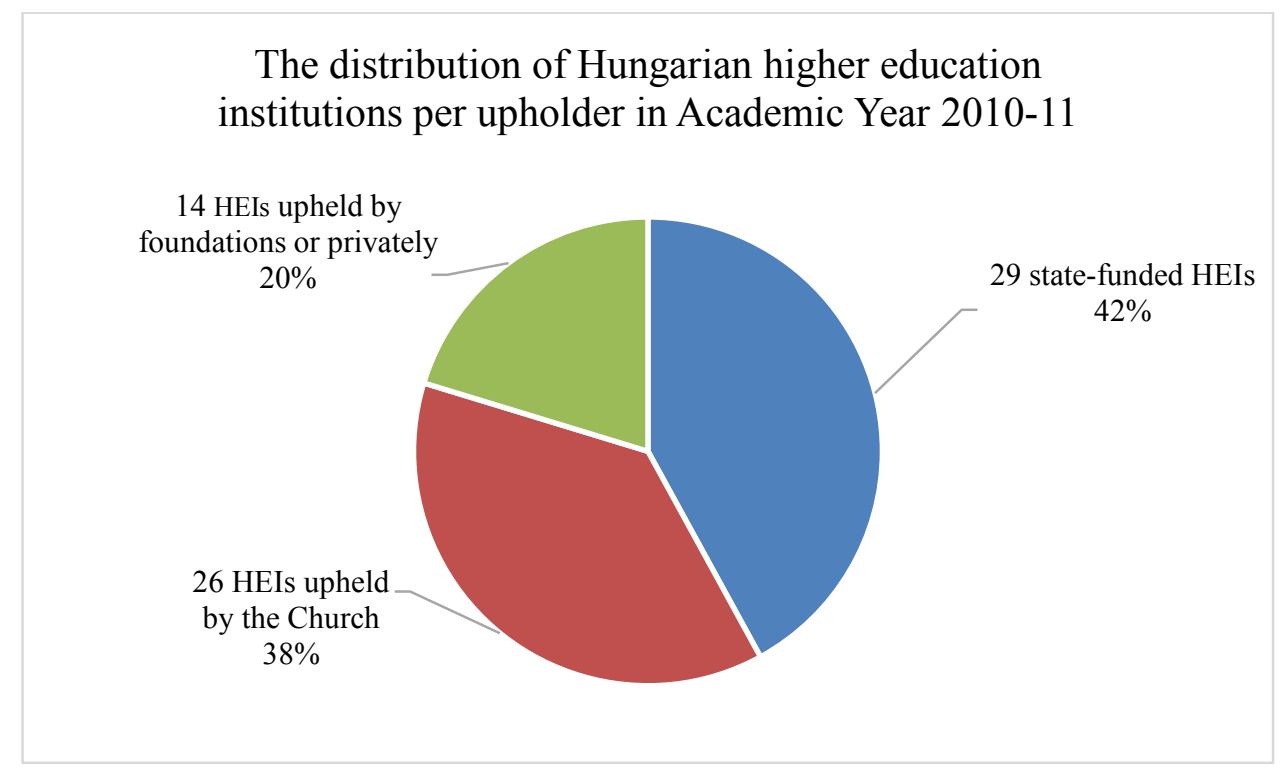

Figure 1: The distribution of Hungarian HEIs per upholder

Source: Office of Education, own editing, 2013. 
A total of 361347 students participated in Hungarian higher education in Academic Year 201011. Almost $90 \%$ of the students were educated at state-funded institutions, a total of 314363 people. Private institutions and foundations provided education for 26433 students, and Church-run institutions for 20551 students. (Figure 2)

The number of students at higher education institutions per upholder in Academic Year 2010-11

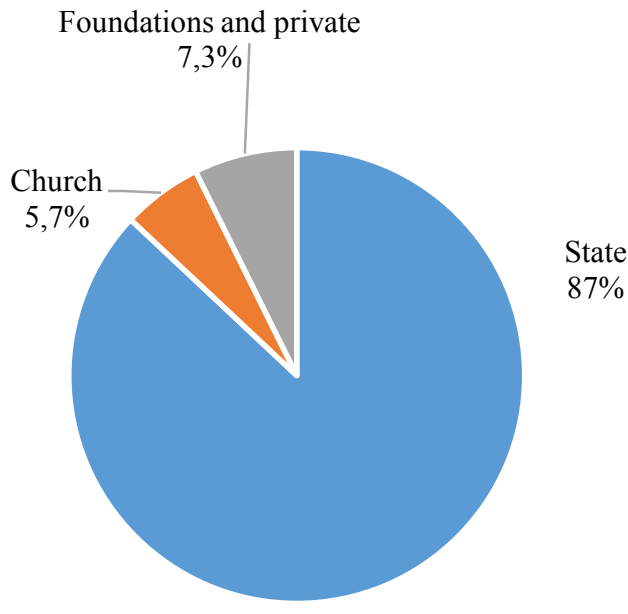

Figure 2: The distribution of students in Academic Year 2010-11

Source: Office of Education, own editing, 2013.

Act CXXXIX of 2005 on higher education provides that a university delivering outstanding quality of education and training, recognised for its scientific excellence in the European Research Area could receive research university status - the conditions are set by the Government of the Republic of Hungary. A research university conveys substantial national and international research, development and innovation, the results of which are implemented to education. It gives talent management priority at all levels of education and provides outstanding performance in doctoral programmes. It also promotes and supports international cooperation in education, science and research in which takes a leading role nationally or regionally. (Complex, 2013) In Academic Year 2010-11, the number of students surpassed 10000 at 13 state-funded universities (Figure 3). It would seem that the institutions with a high number of students are generally associated with excellence, however, the title is conferred on the basis of the criteria prescribed in Act CXXXIX of 2005 on higher education. (Felvi, 2013)

Between 2010 and 2013 University of Szeged, Eötvös Loránd University, University of Debrecen, Semmelweis University and Budapest University of Technology and Economics received research university status. Between 2013 and 2016 each of the five universities from the former period and University of Pécs were honoured with research university status. Budapest Business School and Eszterházy Károly College were promoted to the rank of college of applied sciences. University of Debrecen also received university of national excellence status. Szent István University Faculty of Veterinary Science and Agriculture and Environmental Sciences Faculty, University of Pannonia Faculty of Engineering and Pázmány Péter Catholic University Faculty of Information Technology all received research faculty status. (Edupress, 2013) 


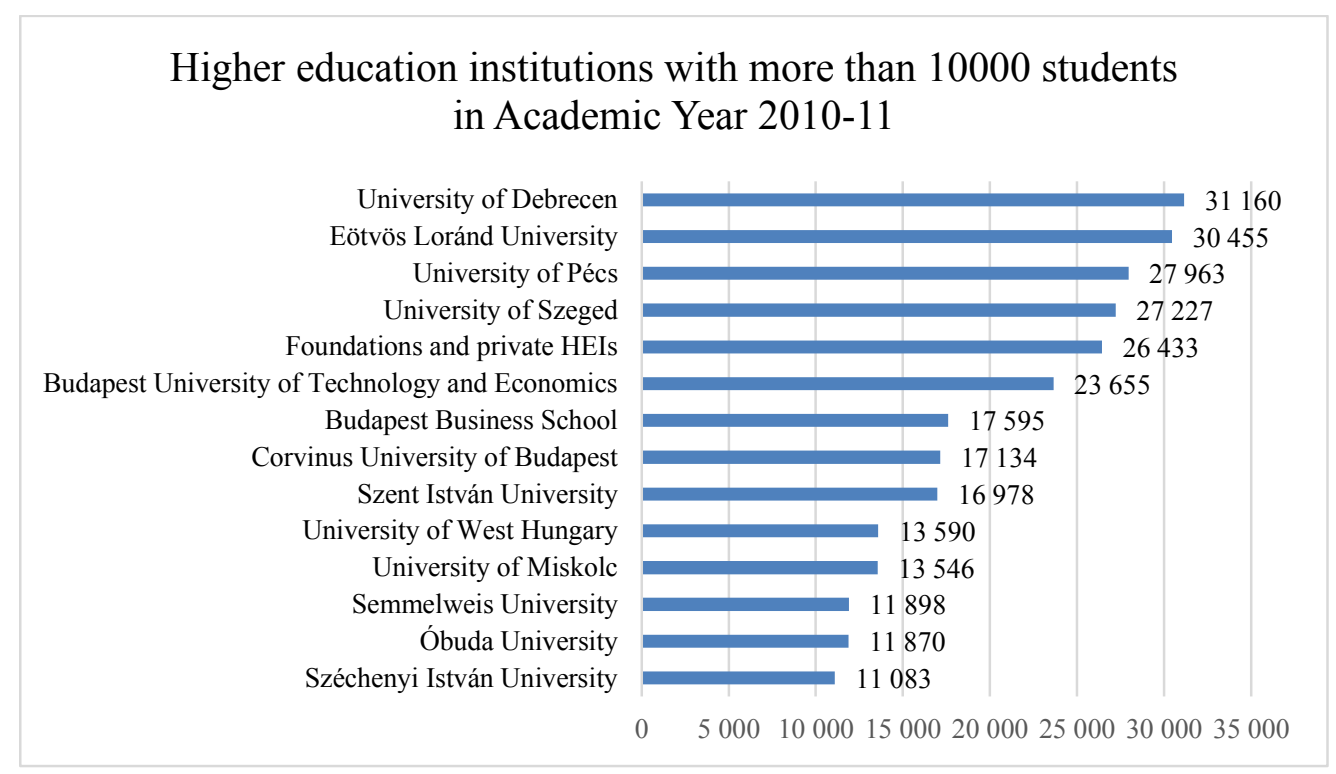

Figure 3: High number of students at HEIs

Source: Office of Education, own editing, 2013.

This study analyses the latest data on the number of students published by the Office of Education for the Academic Year 2010-11. Information can be gained about the organizational structure of higher education through concentration analysis based on the number of students from different higher education institutions. The extent of the accumulated student population in the various institutions of higher education can be statistically determined. The most common way to illustrate concentration is the Lorenz curve, which graphically represents not only the existence but also the degree of concentration. Besides the Lorenz curve, data analysis is performed using the Gini index $(\mathrm{G})$, the concentration coefficient $(\mathrm{C})$ and the HerfindahlHirschman index (HHI). (Papp, 2003)

\section{Results and discussion}

Considering state-funded higher education in Hungary, $57.4 \%$ of students are enrolled in $82.8 \%$ of the institutions. Therefore only $18.9 \%$ of the institutions account for educating almost half of the student population (43.6\%). (Figure 4) Thus, a certain degree of concentration can be observed in terms of the number of students and institutions. From the Gini's measure of dispersion $(\mathrm{G})$ the concentration coefficient $(\mathrm{C})$ can be calculated, which shows a slightly lower than mediocre concentration. (Figure 5) (Korpás, 1996)This result is in line with the statement of the International Centre for Higher Education Research that the institutional system of Hungarian higher education is sufficiently concentrated. (Berács et al., 2013) 


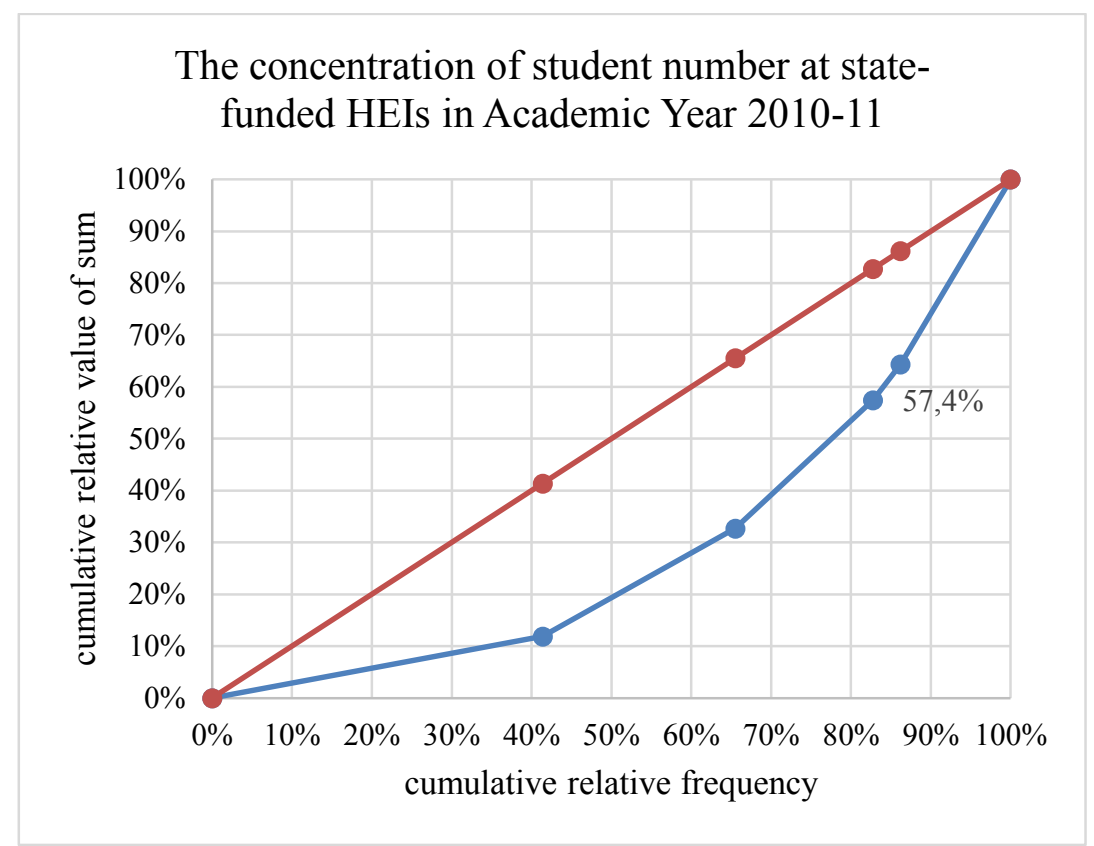

Figure 4: The concentration of student number at HEIs

Source: Office of Education, own editing, 2013.

$$
\begin{gathered}
G=\frac{\sum_{i=1}^{k} \sum_{j=1}^{k} f_{i} f_{j}\left|X_{i}-X_{j}\right|}{N^{2}}=8760,9 \\
C=\frac{G}{2 \bar{X}}=0,42
\end{gathered}
$$

Figure 5: Gini's measure of dispersion $(G)$ the concentration coefficient $(C)$ Source: Own editing, 2013.

Basically, the various methods of calculating concentration are for measuring market concentration. However, in the field of higher education services reported concentrations may be important in the non-business sector as well. The Herfindahl-Hirschman index (HHI) measures the degree of concentration in two ways. First, it takes into account all state-funded higher education institutions as participants. Second, it reflects the difference in size between them, in terms of student numbers. The formula of the Herfindahl-Hirschman index is as follows:

where

$$
H H I=\sum_{i=1}^{n}\left(S_{i}\right)^{2}=611,4
$$

$\mathrm{S}_{\mathrm{i}}=$ the number of students at the $\mathrm{i}^{\mathrm{th}}$ state-funded higher education institution

$\mathrm{n}=$ the total number of state-funded higher education institutions

The index is considered low in this case, which can be explained by the numerous market participants, that is the number of higher education institutions. The highest value of the index is 10000, which means perfect monopoly. In the present case, under the value of 1800 the public interest is secured due to the state paying attention to proper market functioning. (Papp, 2003)

The number of full-time undergraduate students was 157315 in Academic Year 2010-11 in Hungary. 23\% of them, which means 36293 students, participated in management and business education. It was in this particular area that most private higher education institutions offered 
programmes. Regarding the Academic Year 2010-11, 17\% of full-time undergraduate students attended private higher education institutions. (Diagram 1) (Office of Education, 2013)

Distribution of full-time undergraduate management and business students per upholder in Academic Year 2010-11

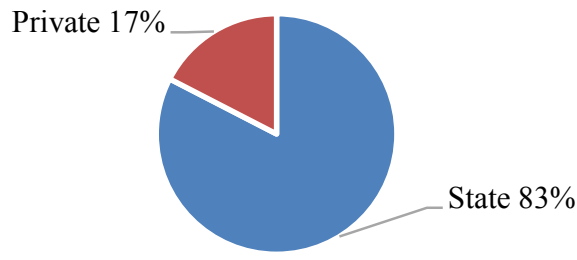

Diagram 1: Distribution of full-time undergraduate management and business students Source: Office of Education, own editing, 2013.

In the field of economic science, three economics and seven business bachelor programmes were advertised on the online admissions website (www.felvi.hu), and 14 master's degree programmes for the Academic Year 2013-14. (Table 1) The most popular undergraduate majors are business management, tourism and hospitality, and finance and accounting. (Diagram 2)

Table 1: Economic science programmes in Hungary

\begin{tabular}{|c|c|c|c|}
\hline \multicolumn{2}{|c|}{ BACHELOR } & \multirow{2}{*}{\multicolumn{2}{|c|}{ MASTER'S }} \\
\hline ECONOMICS & BUSINESS & & \\
\hline $\begin{array}{l}\text { 1. applied } \\
\text { economics }\end{array}$ & 1. human resources & $\begin{array}{l}\text { 1. insurance and } \\
\text { financial } \\
\text { mathematics }\end{array}$ & $\begin{array}{l}\text { 2. international } \\
\text { economics and } \\
\text { management }\end{array}$ \\
\hline $\begin{array}{l}\text { 2. economic } \\
\text { analysis }\end{array}$ & $\begin{array}{ll}\text { 2. } & \text { business } \\
\text { management }\end{array}$ & $\begin{array}{l}\text { 3. economic and } \\
\text { mathematical } \\
\text { analysis }\end{array}$ & 4. finance \\
\hline \multirow[t]{5}{*}{$\begin{array}{l}\text { 3. public } \\
\text { administration }\end{array}$} & $\begin{array}{l}\text { 3. commerce and } \\
\text { marketing }\end{array}$ & $\begin{array}{l}\text { 5. public } \\
\text { management and } \\
\text { public policy }\end{array}$ & $\begin{array}{l}\text { 6. } \text { regional and } \\
\text { environmental } \\
\text { economics }\end{array}$ \\
\hline & $\begin{array}{l}\text { 4. international } \\
\text { business }\end{array}$ & $\begin{array}{l}\text { 7. economic } \\
\text { analysis }\end{array}$ & 8. accounting \\
\hline & $\begin{array}{l}\text { 5. finance and } \\
\text { accounting }\end{array}$ & $\begin{array}{l}\text { 9. logistics } \\
\text { management }\end{array}$ & $\begin{array}{l}\text { 10. } \begin{array}{c}\text { tourism } \\
\text { management }\end{array}\end{array}$ \\
\hline & $\begin{array}{l}\text { 6. tourism and } \\
\text { hospitality }\end{array}$ & 11. marketing & $\begin{array}{l}\text { 12. business } \\
\text { development }\end{array}$ \\
\hline & $\begin{array}{l}\text { 7. business } \\
\text { instructor }\end{array}$ & $\begin{array}{l}\text { 13. Master of } \\
\text { Business } \\
\text { Administration } \\
\text { (MBA) }\end{array}$ & $\begin{array}{l}\text { 14. management } \\
\text { and leadership }\end{array}$ \\
\hline
\end{tabular}

Source: Felvi, own editing, 2013. 


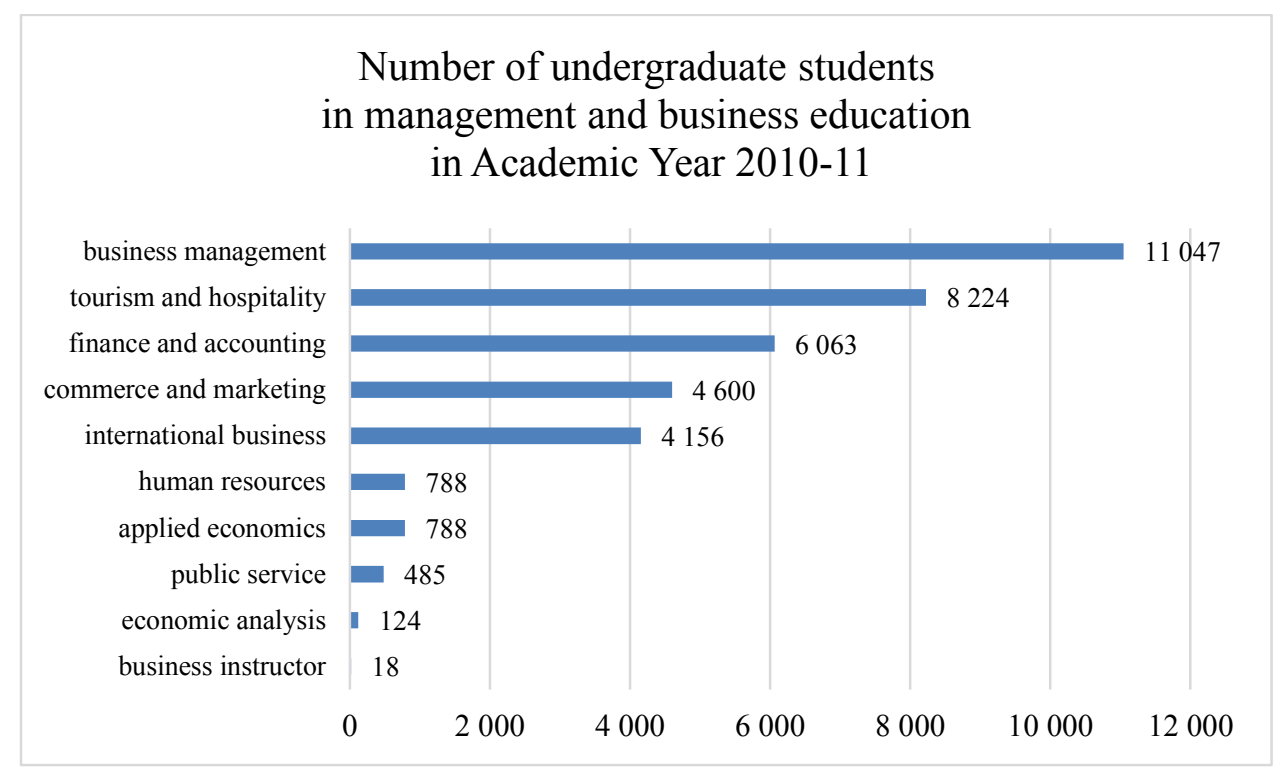

Diagram 2: Number of undergraduate students in management and business education Source: Office of Education, own editing, 2013.

\section{Conclusions}

The findings of the study justify the proposition of the Berács et al. (2013) study, which states that there is no need to intervene into the current institutional composition by initiating further mergers. It seems that this is realised in higher education administration and further proposals for institutional consolidation were withdrawn. According to the International Centre for Higher Education Research, the institutional system of Hungarian higher education is sufficiently concentrated. The great majority of students learn at state-funded universities. However, there are a lot of small colleges, which are private or Church-run institutions. There are eligible government efforts to encourage regional supply from European Union funds. Due to the decline in student population, it has been a difficult situation for small, mostly rural colleges. These colleges are advised to change their profiles, take into account adult education and strengthen short-term training with various types of financial aid. Institutional diversity and efforts for uniqueness, the expansion of institutional missions are all important values to be treated. (Berács et al., 2013)

Considering state-funded universities with a great number of students, they are more likely to gain excellence status. It would seem that institutions with a high number of students are generally associated with excellence, however, the title is conferred on the basis of the criteria prescribed in Act CXXXIX of 2005 on higher education. However, there exist certain institutions promoted to an excellence rank, where student population is not so prominent. In the future, this prestigious act could attract potential applicants to the awarded institution, and lead to a higher student population. Colleges that were awarded the title of college of applied sciences have relatively high student population. This rank of colleges could motivate them towards academic excellence and also mean a prestigious title with the possibility to appeal more prospective students.

Higher education is in a special situation because the institutional framework for universities and colleges - for instance capacity sizes- is determined by the state. However, the institutions must find responses to market challenges. Due to the economic crisis, the Hungarian Government was forced to cut state funding of higher education drastically. 
The number of subsidised places has decreased in the greatest extent in the field of economic sciences. Over the past five years, the financial support of the Hungarian state-funded higher education institutions has been significantly reduced, in real terms less than to its half. (Magyar Rektori Konferencia, 2013) In response to this challenge, higher education institutions may use different marketing strategies. Rapid and unpredictable changes in the socio-economic environment reinforces the need for strategic thinking, and among other things, the marketing approach in higher education. The design, renewal and cost-benefit analysis of programmes is one of the additional tasks and research directions. Labour market expectations should be taken into account, which give entirely new duties to Hungarian institutions. With the nationally coordinated Graduate Career Tracking System it is expected gain information on graduated students and their career development. There is also research potential in the development of education pricing. The institutions will probably meet a multitude of pricing functions in the future, and not only for fee-paying courses. In addition, the development and communication of an appropriate system of grants and loans is another area of the enrolment work. The state quotas are expected to decline in the future, the demographic tide can lead to a reduction in the number of students so the institutions have to look for breakout points. Further research areas may cover exploratory studies on opportunities to retain domestic students and the analysis of regional impacts. Another point is to attract international students by launching foreign language programmes at home and/or abroad. These marketing activities claim entirely new demands on the national higher education institutions. Lastly, the role of the media in informing and influencing applicants is crucial, as well as in conveying the major ratings of rankings. (Kuráth, 2007)

\section{References}

1. Berács, J., Hrubos, I., Temesi, J. (2013): Magyar Felsőoktatás 2012. Stratégiai helyzetértékelés, Projekt jelentés, Budapesti Corvinus Egyetem, Nemzetközi Felsőoktatási Kutatások Központja

Available from: http://unipub.lib.uni-corvinus.hu/1088/

Accessed at 22.08.2013.

2. Browning, H. L., Singelmann, J. (1998): The Transformation of the U.S. Labor Force: The Interaction of Industry and Occupation. In: Bryson, J.R. and Daniels, P.W. (eds.). Service Industries in the Global Economy. The International Library of Critical Writings in Economics, Edward Elgar Publishing 1998, Vol. I: p. 721., p.381-409., ISBN 9781858987187

3. Complex. Hatályos Jogszabályok Gyüjteménye Available from: http://www.complex.hu/kzldat/t0500139.htm/t0500139.htm Accessed at 23.07.2013.

4. Edupress Magyar Oktatási Hírügynökség: Tízmilliárd forint jut a felsőoktatási intézményi kiválóság támogatására (2013)

Available from: http://www.edupress.hu/hirek/index.php?pid=egycikk\&HirID=28561 Accessed at 23.07.2013.

5. Farkasné, F. M. - Molnár, J. (2007): Közgazdaságtan I. Mikroökonómia, Debreceni Egyetem Agrár- és Műszaki Tudományok Centruma, Agrárgazdasági és Vidékfejlesztési Kar, Debrecen, p. 274., p. 257., ISBN 978-963-9732-59-9

6. Felvi (2013) Available from: http://www.felvi.hu/felveteli/szakok kepzesek/szakleirasok/!Szakleirasok/index.php/sza kleirasok/szakleiras kategoriak?kpzt $=7 \&$ kepzes $=\mathrm{A}$ Accessed at 10.08.2013. 
7. Gershuny, J.J., Miles, J.D. (1983): The New Service Economy. Frances Pinter (Publishers), London, p.20-22. In: Papp I. (ed.) (2003): Szolgáltatások a harmadik évezredben. Budapest, Aula Kiadó, p. 542. ISBN 963-9478-58-x

8. Golden, S. Schneller, C. (ed.), The impact of the financial crisis to higher education (2010) Asia-Europe Foundation (ASEF) The 1st Asia-Europe Education Workshop 2526 March 2010, Manila, the Philippines, ISBN 978-981-08-7089-8

9. Jogtár. Hatályos Jogszabályok Gyüjteménye Available from: http://net.jogtar.hu/jr/gen/hjegy_doc.cgi?docid=A1100204.TV Accessed at 10.07.2013.

10. Korpás, A (ed.) (1996): Általános statisztika I., Nemzetközi Tankönyvkiadó, Budapest, p. 231., p. 79-82., ISBN 963-18-8297-7

11. Kuráth, G. (2007): A beiskolázási marketing szerepe a hazai felsőoktatási intézmények vonzerőfejlesztésében, Doktori értekezés, PTE

12. Magyar Rektori Konferencia: A Magyar Rektori Konferencia közleménye, Available from: www.mrk.hu, Accessed at 20.05.2013.

13. Office of Education. Oktatási Hivatal (2013) Available from: http://www.oktatas.hu/felsooktatas/felsooktatasi_statisztikak

Accessed at 21.07.2013.

14. Papp I. (ed.) (2003): Szolgáltatások a harmadik évezredben. Budapest, Aula Kiadó, p. 542., p. 9-34., p. 86-102., ISBN 963-9478-58-x

15. Turban, E., King, D., Chung, H. M. (2000) Electronic Commerce: A Managerial Perspective, London, Prentice Hall Publishers, p.199. In: Papp I. (ed.) (2003): Szolgáltatások a harmadik évezredben. Budapest, Aula Kiadó, p. 542., p. 9-34., ISBN 963-9478-58-x

16. Veres, Z. (2004): Nonbusiness marketing. In: Dinya, L., Farkas, F., Hetesi, E., Veres, Z. (ed.): Nonbusiness marketing és menedzsment, KJK-KERSZÖV Jogi és Üzleti Kiadó Kft., Budapest, p. 416., p. 21-39., ISBN 963-224-787-6

17. Veres, Z. (2009): A szolgáltatásmarketing alapkönyve, Akadémiai Kiadó, Budapest, p. 578., p. 24, p. 507-511., ISBN 978-963-05-8670-2 